\title{
New data on the crab Binkhorstia ubaghsii (Late Maastrichtian; NE Belgium, SE Netherlands)
}

\author{
Barry W.M. van Bakel ${ }^{1}$, John W.M. Jagt ${ }^{2}$, René H.B. Fraaije ${ }^{3}$ \& Yvonne Coole $^{4}$ \\ ${ }^{1}$ Schepenhoek 235, NL-5403 GB Uden, the Netherlands; ${ }^{2}$ Natuurhistorisch Museum Maastricht, de Bosquet- \\ plein 6-7, P.O. Box 882, NL-6200 AW Maastricht; ${ }^{3}$ Oertijdmuseum de Groene Poort, Bosscheweg 80, NL- \\ 5283 WB Boxtel, the Netherlands; ${ }^{4}$ St Maartenslaan 88, NL-6039 BM Stramproy, the Netherlands
}

Keywords: Crustacea, type Maastrichtian, Binkhorstia, systematic placement

\begin{abstract}
Well-preserved material of Binkhorstia ubaghsii reveals some additional information that helps clarify the taxonomic affinities with the Torynommidae of this Late Cretaceous crab from the Maastricht area of Belgium and Netherland
\end{abstract}

\section{Introduction}

Carcinologists dealing with fossil crabs are often faced with difficulties in classifying their material. With only a single or a handful of specimens available, more often than not consisting of only (partial) carapaces, dorsal carapace characters are the sole features to go on. Classification of extant crabs mostly cannot be applied, since ventral morphology is here of prime importance (Guinot, 1977, 1978). Having come to realize that carapace characters may overlap in representatives of unrelated families, in the past decade paleontologists have used the few cases in which crabs are preserved with well-preserved ventral parts with much success (Karasawa, 2003, Guinot \& Tavares, 2001).

Binkhorstia Noetling, 1881, known exclusively from Upper Maastrichtian deposits in the type area of the Maastrichtian Stage (SE Netherlands, NE Belgium), has been placed in different families by various authors. Glaessner (1980) erected the family Torynommidae (Cyclodorippoidea), and included Withersella Wright \& Collins, 1972 and Binkhorstia. Withersella was originally placed in the Carcineretidae Beurlen, 1930, and together with Binkhorstia again assigned to the Carcineretidae by later authors (Collins et al, 1995; Fraaye, 1996; Wright,
1997; Jagt et al., 2000). Many new species of and new data for the largely western Tethyan Carcineretidae have been described in the past two decades (Feldmann et al., 1999; Feldmann \& Villamil, 2002; Vega \& Feldmann, 1991; Vega et al., 1995; Vega et al., 1997; Vega et al., 2001). Feldmann \& Villamil (2002) included five genera in the Carcineretidae, namely Carcineretes Withers, 1922, Branchiocarcinus Vega et al., 1995, Mascaranada Vega \& Feldmann, 1991, Ophthalmoplax Rathbun, 1935 and Woodbinax Stenzel, 1952. They suggested that Binkhorstia and Withersella should be retained in the Cyclodorippidae Ortmann, 1892.

\section{Results}

The new material of Binkhorstia ubaghsii consists of three more or less complete specimens all collected from the uppermost Nekum Member (Maastricht Formation), at the CBR-Romontbos quarry in Eben Emael, NE Belgium. Here, B. ubaghsil is fairly common and is found in association with Paranecrocarcinus quadriscissus Noetling, 1881, "Pseudoraninella" muelleri (van Binkhorst, 1857), Homolopsis declinata Collins et al., 1995, Eumorphocorystes sculptus (van Binkhorst, 1857), Paguristes? florae Collins et al., 1995 and Lyreidina pyriformis Fraaye \& van Bakel, 1998. Two specimens most likely represent corpses; the third is probably a molt. The best preserved specimen * [NUMBER] has been prepared in detail both dorsally and ventrally, and shows important details at the ventral side with all the abdominal segments, sternites and bases of limbs preserved. The coxae of 


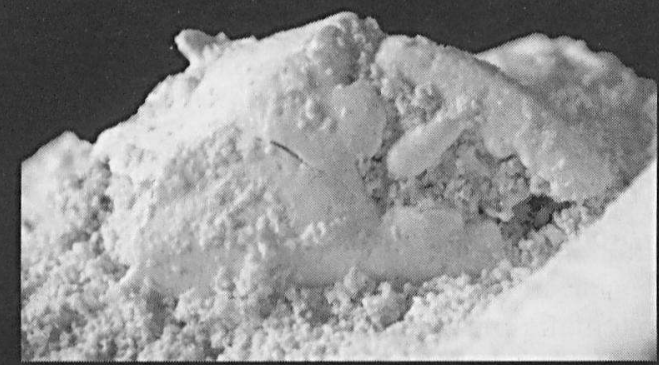

1

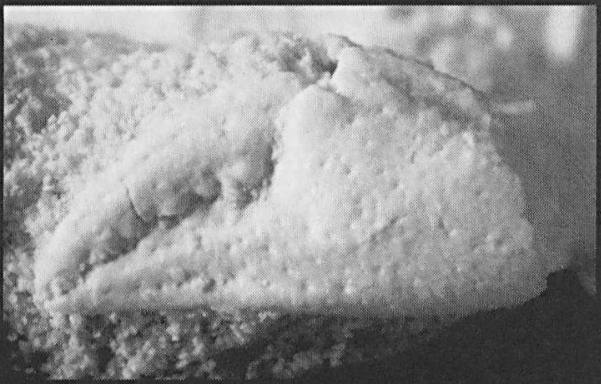

2
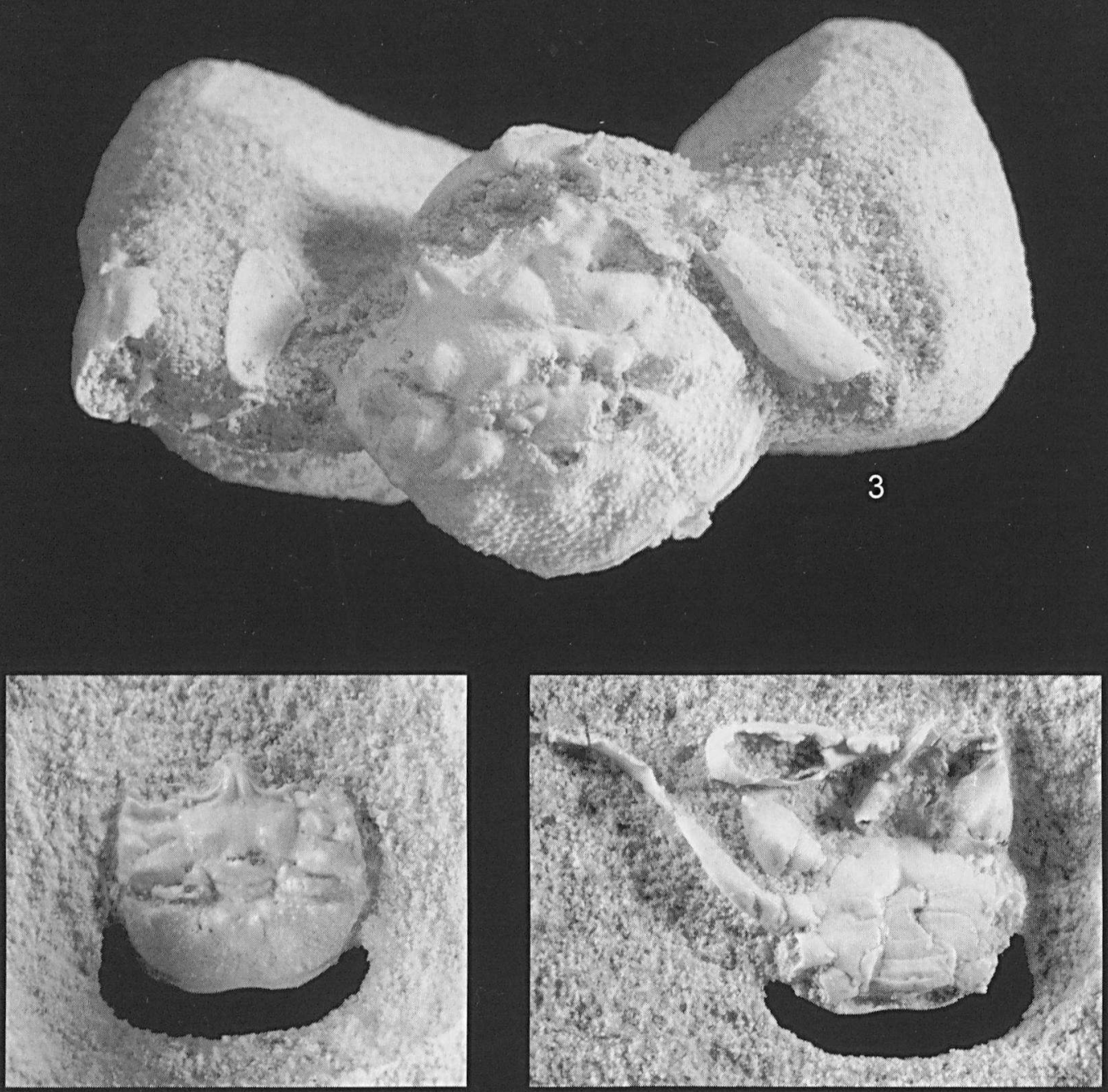
the fifth pair of pereiopods are diminutive, and situated laterally of the small and slender first abdominal segment, covered by the posterior carapace margin. The second corpse shows both chelipeds, some disarticulated limb fragments, and a wellpreserved, broad sternum. The carapace shows the unique spatulated rostrum, a feature that may be diagnostic for the family. Body parts of the third specimen, a presumed molt, lie on top of the carapace, but with the left-hand cheliped preserved the identification as $B$. ubaghsii is indisputed. Pereiopods P2, P3 and P4 are partially exposed and extremely flattened, assumed to have served for swimming.

The holotype of Binkhorstia euglypha Collins et al., 1995 from the upper Meerssen Member at the former Blom quarry (Berg en Terblijt, SE Netherlands), shows details of the ventral parts as well, though not described in detail in the original description. A re-examination of the original material, together with the new data on $B . u b a g h s i$, should provide more information on this little known genus.

The genus most closely resembling Binkhorstia is the Late Cretaceous Torynomma Woods, 1953. Therefore the correct familial classification of Binkhorstia is Torynommidae Glaessner, 1980. The Aptian genus Withersella has been considered ancestral to Binkhorstia by several authors; we concur. Nevertheless, Binkhorstia shows many similarities to the Carcineretidae, and in particular to Ophthalmoplax. Glaessner (1960) noted that the relationships between the Dorippidae, Dakoticancridae and Portunidae should be investigated. The many additions since that paper, together with the new discoveries and a re-examination of published material, could well form the foundation of such a study.

\section{Acknowledgements}

We thank Rudi W. Dortangs (Amstenrade) for taking photographs, Robert Pieters (Geel) for donation of material.

\section{References}

Beurlen K. 1930. Vergleĩchende Stammesgeschichte. Grundlagen, Methoden, Probleme unter besonderer Berücksichtigung der höheren Krebse. Fortschr. Geol. Paläont. 8: 317-586.

Binkhorst JT van. 1857. Neue Krebse aus der Maestrichter Tuffkreide. Verh. Naturhist. Ver. preuss. Rheinl. Westf. 14: 107-110.

Collins JSH, Fraaye RHB \& Jagt JWM. 1995. Late Cretaceous anomurans and brachyurans from the Maastrichtian type area. Acta palaeont. pol. 40: 165-210.

Feldmann RM, Villamil T. 2002. A new carcineretid crab (Upper Turonian, Cretaceous) of Colombia. Jour. Paleo. 76: 718724.

Feldmann RM, Villamil T, Kaufiman EG. 1999. Decapod and stomatopod crustaceans from mass mortality lagerstatten: Turonian (Cretaceous) of Colombia. Jour. Paleo. 73: 91-101.

Fraaye RHB. 1996. Late Cretaceous swimming crabs: radiation, migration, competition, and extinction. Acta geol pol. 46: 269-278.

Fraaye RHB, van Bakel BWM. 1998. New raninid crabs (Crustacea, Dećapoda, Brachyura) from the Late Maastrichtian of the Netherlands. Geöl. Mĭmbouw 76: 293-299.

Glaessner MF. 1960. The fossil decapod Crustacea of New Zealand and the evolution of the Order Decapoda. N.Z. Geol. Surv, Paleontol. Bull. 310: 1-63.

Glaessner MF. 1980. New Cretaceous and Tertiary crabs (Crustacea: Brachyura) from Australia and New Zealand. Trans. Roy. Soc. S. Austr. 104: 171-192.

Guinot D. 1977. Propositions pour une nouvelle classification des Crustacés Décapodes Brachyoures. C.R. Acad. Sci. Paris D285: 1049-1052.

Guinot D. 1978. Principes d'une classification évolutive des Crustacés Décapodes Brachyoures. Bull. Biol. Fr, Belg. 112: 209-292.

Guinot D, Tavares M. 2001. Une nouvelle famille de Crabes du Crétacé, et la notion de Podotremata Guinot, 1977 (Crustacea, Decapoda, Brachyura). Zoosystema 23: 507-546.

Jagt JWM, Fraaye RHB \& van Bakel BWM. 2000. Late Cretaceous decapod crustacean faunas of northeast Belgium and the southeast Netherlands. Studi e Ricerche, Assoc. Amici Mus. civ. 'G. Zannato', Montecchio Maggiore (Vicenza): 37 42.

Karasawa H, Kato H. 2003. The systematic status of the genus Miosesarma Karasawa, 1989 with a phylogenetic analysis within the family Grapsidae and a review of fossil records (Crustacea: Decapodax Brachyura). Paleont. Res. 5: 259-275.

Noetling F. 1881. Ueber einige Brachyuren aus dem Senon von Mastricht [sic] und dem Tertiär Norddeutschlands. $Z$. dt. geol. Ges. 33: 357-371.

$\leftarrow$

Fig. 1. Binkhorstia ubaghsï (van Binkhorst, 1857); Upper Nekum̄ Member (Maastricht formation, Late Maastrichtian) of CBRRomontbos quarry, Eben Emael (NE Belgium). 1, Right cheliped. 2, Left cheliped of the same specimen. 3, Dorsal view of this specimen, showing complete carapace, both claws and limb fragments. 4 , Dorsal view. 5 , Ventral view, showing the delicate preservation. 


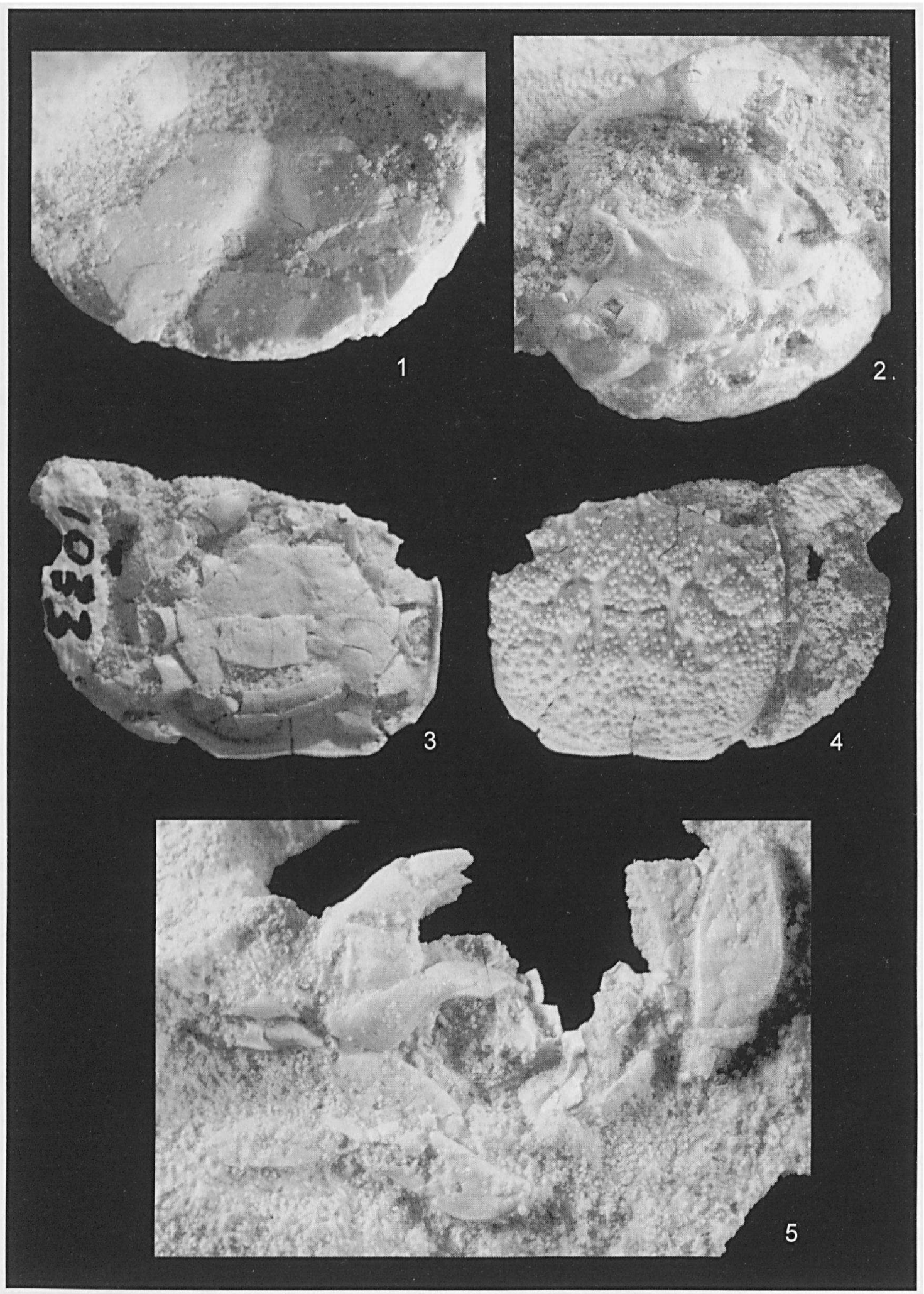


Ortmann A. 1892. Die Decapoden-Krebse des Strassburger Museums. V. Theil. Die Abteilungen Hippidae, Dromilidae, und Oxystomata. Zool. Jb. 6: 532-588.

Rathbun MJ. 1935. Fossil Crustacea of the Atlantic and Gulf Coastal plain. Geol. Soc. Am., Spec. Paper 2: 1-160.

Stenzel HB. 1952. Decapod crustaceans from the Woodbine Formation of Texas. U. S. Geol. Surv. Prof. Paper 242: 212217.

Vega FJ, Feldmann RM. 1991. Fossil crabs (Crustacea: Decapoda) from the Maastrichtian Difunta Group, northeastern Mexico. Ann. Carnegie Mus. 60: 163-177.

Vega FJ, Feldmann RM, Ocampo AC, Pope KO. 1997. A new species of Late Cretaceous crab (Brachyura: Carcineretidae) from Albion Island, Belize. Jour. Paleo. 71: 615-620.

Vega FJ, Feldmann RM, Sour-Tovar F. 1995. Fossil crabs
(Crustacea: Decapoda) from the Late Cretaceous Cárdenas Formation, east-central Mexico. Jour. Paleo. 69: 340-350.

Vega FJ, Feldmann RM, García-Barrera P, Filkorn H, Pimentel F \& Avendaño J. 2001. Maastrichtian Crustacea (Brachyura: Decapoda) from the Ocococuautla Formation in Chiapas, southeast Mexico. Jour. Paleo. 75: 319-329.

Withers TH. 1922. On a new brachyurous crustacean from the Upper Cretaceous of Jamaica. Ann. Mag. Nat. Hist. 10: 534541.

Woods JT. 1953. Brachyura from the Cretaceous of central Queensland. Mem. Qld Mus. 13: 50-57.

Wright CW. 1997. New information on Cretaceous crabs. Bull.Nat. Hist. Mus. Lond. (Geol.) 53: 135-138.

Wright CW, Collins JSH. 1972. British Cretaceous Crabs. Palaeontogr. Soc. Monogr. 126 (533): 1-114.

$\leftarrow$

Fig. 2. Binkhorstia ubaghsii (van Binkhorst, 1857) and Binkhorstia euglypha Collins, Fraaye \& Jagt, 1995. 1, Ventral view, with details of the sternum of $B$. ubaghsil. 2, Orbital view of this specimen, showing the unique spatulated rostrum. 3, Binkhorstia euglypha Collins, Fraaye \& Jagt, 1995, ventral view of holotype (MAB. k. 1033) from the upper part of the Meerssen Member (latest Maastricht formation) of the former Blom quarry, Berg en Terblijt (SE Netherlands). 4, Dorsal view of the holotype. 5, Dorsal view of assumed molt, $B$, ubaghsil, showing the left-hand claw, and flattened pereiopods. 